\title{
Research Progress of Preparation Methods of Graphene Nanocomposites for Low-Temperature Fuel Cells and Lithium-Ion Batteries
}

DOI: $10.15255 / K U I .2016 .005$ KUI-17/2016

Review

Received February 17, 2016 Accepted April 15, 2016

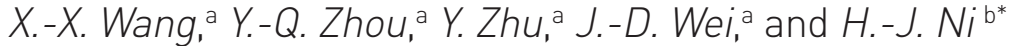 \\ a School of Mechanical Engineering, Nantong University, Nantong, Jiangsu, P. R. China \\ bSchool of Mechanical Engineering, Nantong University, No. 9, Seyuan Road, Nantong, \\ Jiangsu, P. R. China
}

\section{\| Abstract}

Because of its unique two-dimensional structure, huge specific surface area, high electrical conductivity, and other excellent performances, graphene has shown great potential for application in catalysis, electronics, sensors, energy storage, and other areas. Especially, graphene nanocomposites have been found to be promising catalyst support for low-temperature fuel cells, and as anode nanomaterials for high reversible capacity and excellent rate capability for lithium-ion batteries, which has triggered a new round of research hotspot. Preparation methods of graphene nanocomposites mainly for low-temperature fuel cells are reviewed. Particularly, the research progress and principles of physical preparation methods (molecular beam epitaxy), chemical preparation methods (chemical reduction, electrochemical deposition and hydrothermal/solvothermal methods, etc.) and high-energy ball milling are summarized. Research outlook of graphene nanocomposites for low-temperature fuel cells are prospected.

\section{|| Keywords}

Graphene nanocomposites, preparation methods, low-temperature fuel cells, electrocatalysts, anode materials

\section{Introduction}

In 2004, Geim et al. ${ }^{1}$ used the micro-mechanical exfoliation method to obtain graphene with a two-dimensional structure. Graphene has a very high specific surface area $\left(2630 \mathrm{~m}^{2} \mathrm{~g}^{-1}\right)$, an electron mobility exceeding $15000 \mathrm{~cm}^{2} \mathrm{~V}^{-1} \mathrm{~S}^{-1}$ at room temperature, and a thermal conductivity of about $5000 \mathrm{~W} \mathrm{~m}^{-1} \mathrm{~K}^{-1}$. Moreover, graphene has an ambipolar field-effect and quantum Hall ferromagnetic characteristics. ${ }^{2-5}$ Benefiting from the above superior properties, graphene has been highly attractive both in industrial and fundamental research. For example, in lithium-ion batteries, many metal oxide anode materials have used graphene sheets as an ideal matrix material. Similar to carbon nanotubes, graphene is difficult to produce as a single material, and it is mainly used to produce a new type of composite material with excellent properties. Therefore, graphene composite materials find their application in the fields of catalysis, electrochemistry, and biomedical. ${ }^{6-8}$ Accordingly, preparation of graphene nanocomposites using diverse methods from a variety of precursors has been intensively studied.

In recent years, the development of clean, efficient, and new energy sources has become a hot topic. Fuel cells are widely applied in the automobile, stationary power generation, aerospace and other fields ${ }^{9-13}$ due to their high energy conversion efficiency and battery device reliability. The widely used catalyst supports are Vulcan XC-72, carbon nanofibers, and carbon nanotubes, ${ }^{14-17}$ which partly relieve the problems of high cost and anode catalyst poisoning. However, these materials still cannot meet the require-

\footnotetext{
* Corresponding author: Professor Hongjun Ni
}

e-mail: ni.hj@ntu.edu.cn ments as an ideal electrocatalyst of stable performance under repeated start-stop cycles or high-potential conditions. Due to the uniform distribution of electrochemically active sites, catalyst particles supported on the surface of graphene can decrease the over potential of catalytic reactions obviously. ${ }^{18}$ In lithium-ion batteries, the demand for research of anode materials with enhanced energy capacity and cycle life has increased a great deal. Consequently, in order to utilize the advantages of graphene, it is desirable to prepare highly efficient graphene-supported metal electrocatalysts to improve the performance of fuel cells, and as effective anode materials for lithium-ion batteries.

\section{Preparation methods of graphene nanocomposites}

\subsection{Physical preparation methods}

Physical preparation methods usually use light, electricity, and other forms of energy to evaporate materials in a vacuum or inert atmosphere and deposit the gaseous atoms or molecules to form nanoparticles. Reported methods include molecular beam epitaxy, thermal evaporation and spray technology. ${ }^{19,20}$

Molecular beam epitaxy (MBE) is a method for growth of thin films crystallized in high quality on crystal substrates. In a high vacuum, the vapour generated by heating the furnace containing various components, formed a single crystal layer on the substrate through spray from a small hole of the furnace directly. While controlling the molecular beam and the substrate at the same time, the molecules or atoms could arrange in a layer-by-layer manner. 
Hernández-Rodríguez et al. ${ }^{21}$ used a MBE growth method to obtain graphene on Pt and Au using evaporation of carbon atoms from a carbon solid-source in ultra-high vacuum conditions. This method opens up new possibilities for the formation of graphene on many different substrates.

However, due to the high cost of MBE and high vacuum degree, it needs to avoid impurity contamination in the evaporator. MBE requires strict control of smoothness, stability, and purity of the crystal growth parameters. Therefore, how to control the crystal growth parameters is one of the technical problems to be solved.

\subsection{Chemical preparation methods}

\subsubsection{Chemical reduction method}

Chemical reduction is a common method for preparation of nanocomposites. Typical procedures include stirring the aqueous mixture of noble metal precursors (e.g. $\mathrm{HAuCl}_{4}$ $\mathrm{K}_{2} \mathrm{PtCl}_{4}$ and $\mathrm{H}_{2} \mathrm{PdCl}_{6}$ et al.) and catalyst carriers in order to make them fully dispersed at first, and then adding reducing agents in the liquid phase. Finally, the ionic reactants are reduced to metals to successfully prepare the target nanocomposites. Reducing agents include commonly used ethylene glycol, sodium borohydride, and hydrazine hydrate.

Liu et al.22 prepared Pt/graphene nanocomposites as the anode electrocatalyst for direct borohydride fuel cell by an ethylene glycol reduction method. At 298 K, the maximum power density of Pt/graphene nanocomposites was $42 \mathrm{~mW} \mathrm{~cm}^{-2}$, apparently higher than that of Pt/Vulcan $\mathrm{XC}-72 \mathrm{R}$ nanocomposites $\left(34 \mathrm{~mW} \mathrm{~cm}^{-2}\right)$. Wang et al. ${ }^{23}$ prepared $w=40 \%$ Pt/graphene composite as the electrocatalyst for oxygen reduction reaction by sodium borohydride chemical co-reduction. The results showed that the initial activity of the obtained Pt/graphene was lower than that of $\mathrm{Pt} / \mathrm{C}$ because of the inhibition of oxygen diffusion. However, the subsequent degradation tests indicated that Pt/graphene (50 \%) was less stable than Pt/C (79\%).

The chemical reduction method is simple, easy to operate, and can be employed in mass-production. However, since the formation of metals occurs in the liquid phase and on the surface of the carriers, the metal cores growing in catalyst particles usually distribute randomly on the surface of the carriers. In addition, the reducing agent and organ- ic solvents can deteriorate the binding strength between graphene and nanoparticles. Thus, the performance of the nanocomposites synthesized using this method may not be very high.

\subsubsection{Sol-gel method}

The sol-gel method usually uses metal alkoxides or metal chlorides as the precursors and treats them by a series of hydrolysis and condensation reactions. Finally, the cured composite catalysts are prepared after drying and calcining. ${ }^{24}$ Sun et al. ${ }^{25}$ prepared five different nanoparticles of $\mathrm{Pt} /$ sulfonated graphene $(\mathrm{Pt} / \mathrm{sG})$ as anode electrocatalysts on alkaline direct ethanol fuel cell by the sol-gel method. The different particle diameters of the electrocatalysts were $1.7 \mathrm{~nm}, 2.5 \mathrm{~nm}, 3.5 \mathrm{~nm}, 4.4 \mathrm{~nm}, 13.9 \mathrm{~nm}$, respectively (Table 1). Theoretical calculations showed that the sulfonic acid groups in $\mathrm{SG}$ can enhance the adsorption energy of $\mathrm{Pt}$, and in consequence decrease the adsorption capacity of $\mathrm{CO}$ on Pt. The experimental results showed that Pt/sG $(2.5 \mathrm{~nm})$ has the highest peak current of CV $\left(3480 \mathrm{mAg}^{-1}\right.$, a ratio to $\mathrm{Pt}$ mass). The ethanol oxidation activity of $\mathrm{Pt} / \mathrm{sG}$ $(2.5 \mathrm{~nm})$ was also higher than that of carbon black supported Pt of the same size $(2.5 \mathrm{~nm})$.

The sol-gel method is an effective method for preparing thin-film coating materials. The method works at low reaction temperatures and is easy to conduct, but there still exist many confounding factors in the process of forming a sol. Meanwhile, a rubber reunion phenomenon is apt to occur.

\subsubsection{Electrochemical deposition method}

The electrochemical deposition method has rapidly developed into a technology of great industrial importance. Certain substrates were selected as the electrodes and a mixed solution of catalyst precursors was used as the electrolyte of electrolytic cells. The electrochemical deposition method can easily obtain uniform distribution of the nanoparticle layer by controlling the current, potential and deposition time. ${ }^{26}$ Shi Guoyu et al. ${ }^{27}$ used ITO conductive glass substrates as the electrode to prepare $\mathrm{PtCo} /$ graphene nanosheets composite electrocatalysts by the constant potential deposition method. The results showed that when the ratio of $\mathrm{Pt}$ and Co was $1: 2.93$, the electro-catalytic

Table 1 - Particle size effects of Pt/sG nanoparticles on ethanol electrooxidation ${ }^{25}$

Tablica 1 - Učinci veličine nanočestica Pt/sG na elektrooksidaciju etanola ${ }^{25}$

\begin{tabular}{|c|c|c|c|c|c|c|}
\hline \multirow{2}{*}{$\begin{array}{l}\text { Sample } \\
\text { Uzorak }\end{array}$} & \multirow{2}{*}{$\begin{array}{l}\text { Synthesis } \mathrm{pH} \\
\mathrm{pH} \text { sinteze }\end{array}$} & \multirow{2}{*}{$\begin{array}{l}\text { Average particle } \\
\text { size/nm } \\
\text { Prosječna veličina } \\
\text { čestica /nm }\end{array}$} & \multirow{2}{*}{$\begin{array}{c}\text { Standard } \\
\text { deviation/nm } \\
\text { Standardna } \\
\text { devijacija/nm }\end{array}$} & \multicolumn{2}{|c|}{$\begin{array}{c}\mathrm{ECSA} / \mathrm{cm}^{2} \\
C(\mathrm{NaOH})=0.1 \mathrm{moll}^{-1}\end{array}$} & \multirow{2}{*}{$\begin{array}{l}\text { ESCA (surface area to Pt mass) } \\
\qquad / \mathrm{m}^{2} \mathrm{~g}^{-1} \\
\text { ESCA (prema masi Pt) } / \mathrm{m}^{2} \mathrm{~g}^{-1}\end{array}$} \\
\hline & & & & $\operatorname{Pt}(110)$ & $\mathrm{Pt}(100)$ & \\
\hline Pt-sG (1.7 nm) & 11.8 & 1.7 & 0.4 & 1.41 & 0.34 & 79.77 \\
\hline Pt-sG (2.5 nm) & 11.3 & 2.5 & 0.6 & 1.42 & 0.43 & 80.04 \\
\hline Pt-sG (3.5 nm) & 6.4 & 3.5 & 0.7 & 0.54 & 0.14 & 30.68 \\
\hline Pt-sG (4.4 nm) & 1.0 & 4.4 & 0.9 & 0.65 & 0.15 & 51.84 \\
\hline Pt-sG (13.9 nm) & $<1$ & 13.9 & 5.8 & 0.41 & 0.11 & 36.14 \\
\hline
\end{tabular}


performance of methanol oxidation was the most superior with a current density to Pt mass ratio reaching $662 \mathrm{Ag}^{-1}$. The PtCo/graphene catalysts prepared by the electrodeposition method are of higher catalytic stability, better oxidation kinetics, and has practical significance on efficient methanol fuel cell.

Preparing electrocatalysts by the electrochemical deposition method has advantages of good controllability, easy operation, and environmental compatibility. However, the obtained metal composite nanoparticles cannot penetrate into the graphene sheets completely but deposit mainly on graphene coating surface and then lead to unreliable binding. Therefore, this method remains to be further studied on the binding strength.

\subsubsection{Hydrothermal/Solvothermal method}

The temperature range of the hydrothermal method is usually between 130 and $250{ }^{\circ} \mathrm{C}$ and the corresponding water vapour pressure is $0.3-4 \mathrm{MPa}$. These conditions are the main differences distinguishing hydrothermal from sol-gel and co-precipitation methods. The hydrothermal method simply generates high vapour pressure in a fixed volume at a high temperature to prepare inorganic nanocomposites. Water plays as both the pressurization agent and chemical reaction media. In such state, water can completely (or partially) dissolve most of the reactants, making the reaction in close homogeneous phase, thus speeding up the reaction. Lee et al. ${ }^{28}$ prepared PtRu/graphene and PtRu/multi-walled carbon nanotubes (PtRu/MWCNT) by the hydrothermal method. The main process includes mixing ethylene gly$\mathrm{col}, \mathrm{H}_{2} \mathrm{PtCl}_{6} \cdot \mathrm{H}_{2} \mathrm{O}, \mathrm{RuCl}_{3}$ and graphene together, adjusting $\mathrm{pH}$ of the mixture to 9 by adding $\mathrm{KOH}$, and then transferring the above mixture to the autoclave, which was followed by annealing at $150{ }^{\circ} \mathrm{C}$ for $5 \mathrm{~h}$. The ratio of electrochemically active surface area to Pt mass of the produced $\mathrm{PtRu} /$ graphene was measured to be $68 \mathrm{~m}^{2} \mathrm{~g}^{-1}$, which was higher than that of PtRu/MWCNT $\left(20 \mathrm{~m}^{2} \mathrm{~g}^{-1}\right)$. The above results showed that compared to PtRu/MWCNT, the $\mathrm{PtRu} /$ graphene electrocatalyst had higher electrochemical activity, longer and higher resistance to $\mathrm{CO}$ poisoning in the process of oxidation of methanol. In addition, the high performance PtRu/graphene prepared by the hydrothermal method can be applied to direct methanol fuel cells as the anode catalyst.

Graphene nanocomposites from the hydrothermal method have characteristics of good crystallinity, less agglomeration, high purity, narrow particle size distribution, and morphology controllability. Currently, electrocatalysts prepared by this method have good electrochemical activity, therefore this method has wide potential applications and is worthy of being further developed.

The solvothermal method is developed on the basis of the hydrothermal method, but the solvent is organic or other rather than water. In the solution under certain temperatures and authogenic pressure, the original mixture reacts chemically. ${ }^{29}$ Typical solvents include: ethylenediamine, methanol, ethanol, benzene, toluene, phenol, and ammonia. The solvothermal process is relatively simple and easy to control. The reaction in a closed system can also effectively prevent the leaking of toxic vapour, as well as avoid the exposure of sensitive precursors to air, thus it is an effective method to prepare nanomaterials. ${ }^{30}$

\subsubsection{Other chemical preparation methods}

Recently, sonochemical processing has been proved a useful technique for preparing nanomaterials. Neppolian et al. ${ }^{31}$ synthesized graphene oxide-supported (GO) monometallic Ag and Au, as well as Au-Ag bimetallic catalysts by a dual frequency sonochemical method. The activities of these catalysts were tested using a 4-nitrophenol (4-NP) reduction process. The results revealed that the bimetallic catalysts showed higher activity than other monometallics. Marinkasa et al. ${ }^{32}$ successfully prepared Pt/graphene, Pt/graphene/carbon black and Pt/graphene/multi-walled carbon nanotube composites by a thermally induced chemical reduction method, and analysed these three composite materials. The results showed that the addition of carbon black particles or multi-walled carbon nanotubes destroyed the structure of graphene and formed a porous layer, which was effective for mass transport, and then the performance PEMFC had improved. Sun Hongmei et al. ${ }^{33}$ successfully constructed three-dimensional porous graphene/PtPd bimetallic hybrids (3DPPG) by combining the solvothermal strategy with the ice template technique. At $180{ }^{\circ} \mathrm{C}$, this group mixed ethylene glycol solution containing GO, precursor of PtPd and polyacrylic acid (PPA) in the reaction vessel. The obtained 3DPPG greatly enhanced the physical activity and stability of methanol oxidation, and provided a new platform for new and efficient electrocatalysts of direct methanol fuel cells.

\subsection{High-energy ball milling}

High-energy ball milling is a combination of physical and chemical methods, and it is an important method for the preparation of nanomaterials. The basic principle is that chemical reactivity of crystalline materials in the process of fine grinding can be activated by the mechanical force, which makes the reaction occur at a lower temperature.

Mondal et al. ${ }^{34}$ transformed graphene oxide to reduced graphene oxide (rGO) by high-energy ball milling, which is a new green and scalable approach to synthesizing $\mathrm{rGO}$ starting from GO. The graphene oxide powder was ballmilled by different zirconium oxide balls of $5 \mathrm{~mm}$ diameter and mass ratio between the ball and GO was kept constant at 20:1. The milling was operated with a rotatory speed at $800 \mathrm{rpm}$ in inert Ar atmosphere. Yu et al. ${ }^{35}$ employed high-energy ball milling to synthesize $\mathrm{ZnO} /$ graphene nanocomposites, and evaluated the product as an anode material in lithium-ion batteries. Their $\mathrm{ZnO}$ nanoparticles were created by a top-down wet-chemistry synthesis process. The ball-milling treatments were performed with a rotatory speed of $500 \mathrm{rpm}$ at room temperature in air atmosphere for $20 \mathrm{~h}$. They found that the synthesized nanocomposite exhibited an initially reversible capacity of $783 \mathrm{mAhg}^{-1}$ and maintained a capacity of $610 \mathrm{mAh} \mathrm{g}^{-1}$ after 500 cycles at $100 \mathrm{mAg}^{-1}$. Rashad et al. ${ }^{36}$ used graphene nanoplatelets and carbon nanotubes as reinforcement fillers to enhance 
Table 2 - Characteristics of different preparation methods used to synthesize graphene nanocomposites Tablica 2 - Karakteristike različitih metoda priprave korištenih za sintezu nanokompozita grafena

\begin{tabular}{l|ll}
\hline \multicolumn{1}{c}{$\begin{array}{c}\text { Preparation methods } \\
\text { Preparativne metode }\end{array}$} & \multicolumn{1}{c}{$\begin{array}{c}\text { Advantages } \\
\text { Prednosti }\end{array}$} & \multicolumn{1}{c}{$\begin{array}{c}\text { Disadvantages } \\
\text { Nedostatci }\end{array}$} \\
\hline $\begin{array}{l}\text { physical methods } \\
\text { fizikalne metode }\end{array}$ & $\begin{array}{l}\text { easy to prepare } \\
\text { jednostavno pripravljanje }\end{array}$ & $\begin{array}{l}\text { difficult to control } \\
\text { teško se kontrolira }\end{array}$ \\
\hline $\begin{array}{l}\text { common preparation methods and basically can } \\
\text { kemijal methods }\end{array}$ & $\begin{array}{l}\text { preparation may be complex and } \\
\text { graphene nanocomposites } \\
\text { cobičajene metode, mogu se sintetizirati uniformni } \\
\text { grafenski nanokompoziti }\end{array}$ & $\begin{array}{l}\text { priprava može biti složena i ne } \\
\text { može se proizvoditi na veliko }\end{array}$ \\
\hline $\begin{array}{l}\text { other methods } \\
\text { (high-energy ball milling) } \\
\text { druge metode } \\
\text { (intenzivno kuglično mljevenje) }\end{array}$ & $\begin{array}{l}\text { reaction can be carried out at a lower temperature } \\
\text { reakcija se može provesti pri nižoj temperaturi }\end{array}$ & $\begin{array}{l}\text { the product size distribution is not } \\
\text { introduced }\end{array}$ \\
& & $\begin{array}{l}\text { raspodjela veličine nije ujednačena } \\
\text { i lako se unose nečistoće }\end{array}$
\end{tabular}

the mechanical properties of AZ31 magnesium alloy by high-energy ball milling, sintering and hot extrusion techniques. They found both graphene and carbon nanotubes increased the mechanical strength of AZ31 magnesium alloy.

With further development, this method will not only be widely used in the preparation of nanomaterials and new metal materials, but also in the preparation of other amorphous and ceramic materials. However, there are still some shortcomings for the ball milling method, such as: (1) the product size distribution is not uniform and it is easy to introduce impurities; (2) some powder materials suffer from dispersion and agglomeration problems; (3) the structures of mills are complex and with many consumable parts. The maintenance cost of the mill renders large-scale production costly and uncompetitive. Therefore, high-energy ball milling is attractive but need further optimization.

\subsection{Summary of the preparation methods of graphene nanocomposites}

Table 2 summarizes the advantages and disadvantages of various methods including physical, chemical, and other preparation methods of graphene nanocomposites.

\section{Conclusion}

Hopefully, the studies on the performance of various graphene nanocomposites preparation methods and their improvements will be more abundant. In the future, research into graphene nanocomposites will focus on the following objectives:

(1) To seek new recipes to reduce the loading amount of noble metal on graphene and increase the catalytic performance, so that graphene-based catalysts can be more attractive by lowering the cost of fuel cells;
(2) To develop new methods of preparation or combining with existing preparation methods to improve the uniformity and stability of graphene nanocomposites electrocatalysts;

(3) To achieve large-scale production of graphene nanocomposites. Currently, methods of graphene-based electrocatalysts are suitable for preparation in the laboratory. For the wider use of graphene-based electrocatalysts, it is necessary to realize a large-scale production and preparation process, which should also be easy to operate and control, as well as pollution-free.

\section{ACKNOWLEDGMENT}

This work was financially supported by a project funded by the Priority Academic Program Development of Jiangsu Higher Education Institutions (PAPD) and Nantong City Applied Research Projects (GY12015020).

\section{List of abbreviations and symbols Popis kratica i simbola}

\begin{tabular}{|c|c|}
\hline 3DPPG & $\begin{array}{l}\text { - three-dimensional porous graphene/PtPd } \\
\text { - trodimenzionalni porozni grafen/PtPd }\end{array}$ \\
\hline 4-NP & $\begin{array}{l}\text { - 4-nitrophenol } \\
\text { - 4-nitrofenol }\end{array}$ \\
\hline $\mathrm{CV}$ & $\begin{array}{l}\text { - cyclic voltammetry } \\
\text { - ciklička voltammetrija }\end{array}$ \\
\hline ECSA & $\begin{array}{l}\text { - electrochemical surface area, } \mathrm{cm}^{2} \\
\text { - elektrokemijska ploština površine, } \mathrm{cm}^{2}\end{array}$ \\
\hline ESCA & $\begin{array}{l}\text { - electron spectroscopy for chemical analysis } \\
\text { - elektronska spektroskopija za kemijsku analizu }\end{array}$ \\
\hline GO & $\begin{array}{l}\text { - graphene oxide } \\
\text { - oksid grafena }\end{array}$ \\
\hline ITO & $\begin{array}{l}\text { - indium tin oxide } \\
\text { - indijev kositrov oksid }\end{array}$ \\
\hline
\end{tabular}




\begin{tabular}{|c|c|}
\hline MBE & $\begin{array}{l}\text { - molecular beam epitaxy } \\
\text { - epitaksija molekulskim snopom }\end{array}$ \\
\hline PEMFC & $\begin{array}{l}\text { - proton exchange membrane fuel cell } \\
\text { - gorivni članak s protonskom izmjenjivačkom } \\
\text { membranom }\end{array}$ \\
\hline PPA & $\begin{array}{l}\text { - polyacrylic acid } \\
\text { - poliakrilna kiselina }\end{array}$ \\
\hline $\mathrm{Pt} / \mathrm{sG}$ & $\begin{array}{l}\text { - Pt/sulfonated graphene } \\
\text { - Pt/sulfonirani grafen }\end{array}$ \\
\hline $\mathrm{PtRu} / \mathrm{MWCNT}$ & $\begin{array}{l}\text { - PtRu/multi-walled carbon nanotubes } \\
\text { - PtRu/višestjenčane ugljikove nanocjevčice }\end{array}$ \\
\hline rGO & $\begin{array}{l}\text { - reduced graphene oxide } \\
\text { - reducirani oksid grafena }\end{array}$ \\
\hline C & $\begin{array}{l}\text { - amount of substance concentration, moll }{ }^{-1} \\
\text { - množinska koncentracija, moll }{ }^{-1}\end{array}$ \\
\hline$w$ & $\begin{array}{l}\text { - mass fraction, } \% \\
\text { - maseni udjel, } \%\end{array}$ \\
\hline
\end{tabular}

\section{References \\ Literatura}

1. K. S. Novoselov, A. K. Geim, S. V. Morozov, D. Jiang, Y. Zhang, S. V. Dubonos, I. V. Grigorieva, A. A. Firsov, Electric field effect in atomically thin carbon films, Science 306 (2004) 666-669, doi: http://dx.doi.org/10.1126/science.1102896.

2. H. Cui, X. B. Zhang, P. Yang, J. F. Su, X. Y. Wei, Y. H. Guo, Spectral characteristic of single layer graphene via terahertz time domain spectroscopy, Optik 126 (14) (2015) 13621365, doi: http://dx.doi.org/10.1016/j.jileo.2015.03.032.

3. W. K. Kiat, R. Ismail, M. T. Ahmadi, Contact effect on the current-voltage characteristic of graphene nanoribbon based schottky diode, J. Comput. Theor. Nanos. 12 (2015) 478483, doi: http://dx.doi.org/10.1166/jctn.2015.3756.

4. W. L. Wang, X. Z. Qin, N. S. Xu, Z. B. Li, Field electron emission characteristic of graphene, J. Appl. Phys. 109 (4) (2011) 044304-044304-7, doi: http://dx.doi. org/10.1063/1.3549705.

5. A. K. Geim, Graphene: status and prospects, Science $\mathbf{3 2 4}$ (5934) (2009) 1530-1534, doi: http://dx.doi.org/10.1126/science.1158877.

6. S. Baradaran, E. Moghaddam, B. Nasiri-Tabrizi, W. J. Basirun, M. Mehrali, M. Sookhakian,M. Hamdi, Y. Alias, Characterization of nickel-doped biphasic calcium phosphate/graphene nanoplatelet composites for biomedical application, Mater Sci. Eng. C 49 (2015) 656-668, doi: http://dx.doi. org/10.1016/j.msec.2015.01.050.

7. A. Kafy, K. K. Sadasivuni, A. Akther, S. K. Min, J. Kim, Cellulose/graphene nanocomposite as multifunctional electronic and solvent sensor material, Mater Lett. 159 (2015) 20-23, doi: http://dx.doi.org/10.1016/j.matlet.2015.05.102.

8. R. Ramachandran, M. Saranya, V. Velmurugan, B. P. C. Raghupathy, S. K. Jeong, A. N. Grace, Effect of reducing agent on graphene synthesis and its influence on charge storage towards supercapacitor applications, Appl. Energy 153 (2015) 22-31, doi: http://dx.doi.org/10.1016/j.apenergy.2015.02.091.

9. H. R. Ellamla, I. Staffell, P. Bujlo, B. G. Pollet, S. Pasupathi, Current status of fuel cell based combined heat and power systems for residential sector, J. Power Sources 293 (2015) 312-328, doi: http://dx.doi.org/10.1016/j.jpowsour.2015.05.050.

10. S. Hardman, A. Chandan, R. S. Wilckens, Fuel cell added value for early market applications, J. Power Sources 287
(2015) 297-306, doi: http://dx.doi.org/10.1016/j.jpowsour.2015.04.056.

11. M. Vohra, J. Manwar, R. Manmode, S. Padgilwar, S. Patil, Bioethanol production: feedstock and current technologies, J. Environ. Chem. Eng. 2 (1) (2014) 573-584, doi: http://dx. doi.org/10.1016/j.jece.2013.10.013.

12. T. Hua, R. Ahluwalia, L. Eudy, G. Singer, B. Jermer, N. Asselin-Miller, S. Wessel, T. Patterson, J. Marcinkoski, Status of hydrogen fuel cell electric buses worldwide, J. Power Sources 269 (2014) 975-993, doi: http://dx.doi.org/10.1016/j.jpowsour.2014.06.055.

13. L. An, T. S. Zhao, Y. S. Li, Carbon-neutral sustainable energy technology: direct ethanol fuel cells, Renew. Sust. Energ. Rev. 50 (2015) 1462-1468, doi: http://dx.doi.org/10.1016/j. rser.2015.05.074.

14. R. M. A. Hameed, R. M. El-Sherif, Microwave irradiated nickel nanoparticles on Vulcan XC-72R carbon black for methanol oxidation reaction in $\mathrm{KOH}$ solution, Appl. Catal. B-Environ. 162 (2015) 217-226, doi: http://dx.doi.org/10.1016/j. apcatb.2014.06.057.

15. J. Goel, S. Basu, Effect of support materials on the performance of direct ethanol fuel cell anode catalyst, Int. J. Hydrogen Energy 39 (2014) 15956-15966, doi: http://dx.doi. org/10.1016/j.ijhydene.2014.01.203.

16. K. Senevirathne, R. Hui, S. Campbell, S. Y. Ye, J. J. Zhang, Electrocatalytic activity and durability of $\mathrm{Pt} / \mathrm{NbO}_{2}$ and $\mathrm{Pt} /$ $\mathrm{Ti}_{4} \mathrm{O}_{7}$ nanofibers for PEM fuel cell oxygen reduction reaction, Electrochim. Acta 59 (2012) 538-547, doi: http://dx. doi.org/10.1016/j.electacta.2011.11.005.

17. R. K. Shervedani, A. Amini, Sulfur-doped graphene as a catalyst support: Influences of carbon black and ruthenium nanoparticles on the hydrogen evolution reaction performance, Carbon 93 (2015) 762-773, doi: http://dx.doi.org/10.1016/j. carbon.2015.05.088.

18. N. Seselj, C. Engelbrekt, J. D. Zhang, Graphene-supported platinum catalysts for fuel cells, Sci. Bull. 60 (2015) 864876, doi: http://dx.doi.org/10.1007/s11434-015-0745-8.

19. N. Zhan, M. Olmedo, G. P. Wang, J. L. Liu, Layer-by-layer synthesis of large-area graphene films by thermal cracker enhanced gas source molecular beam epitaxy, Carbon 49 (6) (2011) 2046-2052, doi: http://dx.doi.org/10.1016/j.carbon.2011.01.033.

20. H. Q. Zhou, Y. C. Qiu, Z. Liu, H. C. Yang, L. J. Hu, J. Liu, H. F. Yang, C. Z. Gu, L. F. Sun, Thickness-dependent morphologies of gold on N-layer graphenes, J. Am. Chem. Soc. 132 (2009) 944-946, doi: http://dx.doi.org/10.1021/ja909228n.

21. I. Hernández-Rodríguez, J. M. García, J. A. Martín-Gago, P. L. de Andrés, J. Méndez, Graphene growth on $\mathrm{Pt}(111)$ and $\mathrm{Au}(111)$ using a MBE carbon solid-source, Diam. Relat. Mater. 57 (2015) 58-62, doi: http://dx.doi.org/10.1016/j.diamond.2015.03.004.

22. X. Liu, L. H. Yi, X. Y. Wang, J. C. Su, Y. F. Song, J. Liu, Graphene supported platinum nanoparticles as anode electrocatalyst for direct borohydride fuel cell, Int. J. Hydrogen Energy 37 (2012) 17984-17991, doi: http://dx.doi.org/10.1016/j. ijhydene.2012.09.136.

23. W. L. Wang, Z. F. Ma, Synthesis and Characteristics of Pt/ graphene by Co-Reduction Method for Oxygen Reduction Reactions, Acta Phys.-Chim. Sin 28 (2012) 2879-2884.

24. A. M. Ciciliati, M. F. Silva, D. M. Fernandes, Fe-doped $\mathrm{ZnO}$ nanoparticles: Synthesis by a modified sol-gel method and characterization, Mater. Lett. 159 (2015) 84-86, doi: http:// dx.doi.org/10.1016/j.matlet.2015.06.023.

25. C. L. Sun, J. S. Tang, N. Brazeau, J. J. Wu, S. Ntais, C. W. Yin, H. L. Chou, E. A. Baranova, Particle size effects of sulfonated 
graphene supported Pt nanoparticles on ethanol electrooxidation, Electrochim. Acta 162 (2015) 282-289, doi: http:// dx.doi.org/10.1016/j.electacta.2014.12.099.

26. S. Kim, S. J. Park, Electroactivity of Pt-Ru/polyaniline composite catalyst-electrodes prepared by electrochemical deposition methods, Solid State lonics 178 (2008) 1915-1921, doi: http://dx.doi.org/10.1016/j.ssi.2007.12.074.

27. G. Y. Shi, Z. H. Wang, F. J. Xia, F. F. Zhang, Y. Z. Xia, Y. H. $\mathrm{Li}$, Electrochemical deposition of graphene supported PtCo composite catalysts for electrocatalytic methanol oxidation, Acta. Chim. Sinica 71 (2013) 227-233, doi: http://dx.doi. org/10.6023/A12080553.

28. S. H. Lee, N. Kakati, S. H. Jee, J. Maiti, Y. S. Yoon, Hydrothermal synthesis of PtRu nanoparticles supported on graphene sheets for methanol oxidation in direct methanol fuel cell, Mater. Lett. 65 (21-22) (2011) 3281-3284, doi: http://dx.doi. org/10.1016/j.matlet.2011.07.025.

29. W. Zhang, Z. X. Yin, A. Chun, J. Y. Yoo, G.W. Diao, Y. S. Kim, Y. Z. Piao, Rose rock-shaped nano $\mathrm{Cu}_{2} \mathrm{O}$ anchored graphene for high-performance supercapacitors via solvothermal route, J. Power Sources 318 (2016) 66-75, doi: http://dx.doi. org/10.1016/j.jpowsour.2016.04.006.

30. E. R. Ezeigwe, M. T. T. Tan, P. S. Khiew, C. W. Siong, Solvothermal synthesis of graphene- $\mathrm{MnO}_{2}$ nanocomposites and their electrochemical behaviour, Cream Int. 41 (2015) 11418-11427, doi: http://dx.doi.org/10.1016/j.ceramint.2015.05.105.

31. B. Neppolian, C. Wang, M. Ashokkumar, Sonochemically synthesized mono and bimetallic Au-Ag reduced graphene oxide based nanocomposites with enhanced catalytic activity, Ultrason. Sonochem. 21 (2014) 1948-1953, doi: http:// dx.doi.org/10.1016/j.ultsonch.2014.02.006.

32. A. Marinkasa, F. Arena, J. Mitzel, G. M. Prinz, A. Heinzel, V. Peinecke, H. Natter, Graphene as catalyst support: The influences of carbon additives and catalyst preparation methods on the performance of PEM fuel cells, Carbon 58 (2013) 139-150, doi: http://dx.doi.org/10.1016/j.carbon.2013.02.043.

33. H. M. Sun, L. Y. Cao, L. H. Lu, Three dimensional porous graphene/PtPd bimetallic hybrids as high-performance electrocatalyst for methanol oxidation, Acta Chim. Sinica 71 (2013) 579-584, doi: http://dx.doi.org/10.6023/A12110927.

34. O. Mondal, S. Mitra, M. Pal, A. Datta, S. Dhara, D. Chakravorty, Reduced graphene oxide synthesis by high energy ball milling, Mater. Chem. Phys. 161 (2015) 123-129, doi: http:// dx.doi.org/10.1016/j.matchemphys.2015.05.023

35. M. P. Yu, D. L. Shao, F. Y. Lu, X. Sun, H. T. Sun, T. Hu, G. K. Wang, S. Sawyer, H. Qiu, J. Lian, ZnO/graphene nanocomposite fabricated by high energy ball milling with greatly enhanced lithium storage capability, Electrochem. Commun. 34 (2013) 312-315, doi: http://dx.doi.org/10.1016/j. elecom.2013.07.013.

36. M. Rashad, F. S. Pan, J. Y. Zhang, M. Asif, Use of high energy ball milling to study the role of graphene nanoplatelets and carbon nanotubes reinforced magnesium alloy, J. Alloys Compd. 646 (2015) 223-232, doi: http://dx.doi. org/10.1016/j.jallcom.2015.06.051.

\title{
SAŽETAK
}

\author{
Napredak u istraživanju metoda priprave nanokompozita grafena \\ za niskotemperaturne gorivne ćelije i litij-ionske baterije \\ Xingxing Wang, ${ }^{a}$ Yanqin Zhou, ${ }^{a}$ Yu Zhu, Jindong Wei, and Hongjun Nib*
}

\begin{abstract}
Zbog jedinstvene dvodimenzionalne strukture, velike specifične površine, visoke električne vodljivosti te niza drugih izvrsnih svojstava, grafen ima veliki potencijal za primjenu u katalizi, elektronici, senzorima, skladištenju energije i drugim područjima. Nanokompoziti grafena obećavajući su nosači za katalizatore za niskotemperaturne gorivne ćelije te anodni nanomaterijali za brze litij-ionske baterije s visoko reverzibilnim kapacitetom, što je potaknulo niz novih istraživanja.

Prikazane su metode kojim se pripravljaju nanokompoziti grafena ponajprije za niskotemperaturne gorivne ćelije. Posebno je dan sažetak napretka u istraživanjima i principima fizikalnih (epitaksija molekulskim snopom) i kemijskih metoda priprave (kemijska redukcija, elektrokemijska depozicija, hidrotermalne/solvotermalne metode itd.) te intenzivnog kugličnog mljevenja (high-energy ball milling). Razmatrane su mogućnosti primjene nanokompozita grafena u niskotemperaturnim gorivnim ćelijama.
\end{abstract}

\section{Ključne riječi}

Nanokompoziti grafena, metode priprave, niskotemperaturne gorivne ćelije, elektrokataliza, anodni materijali

\footnotetext{
a School of Mechanical Engineering, Nantong

University, Nantong, Jiangsu, Kina

${ }^{b}$ School of Mechanical Engineering, Nantong

University, No. 9, Seyuan Road, Nantong,

Jiangsu, Kina
}

Pregledni rad

Prispjelo 17. veljače 2016 Prihvaćeno 15. travnja 2016. 